\title{
Cryotherapy compared with trichloroacetic acid in treating genital warts
}

\author{
M J GODLEY, C S BRADBEER, M GELLAN, R N T THIN \\ From the Department of Genitourinary Medicine, St Thomas' Hospital, London
}

SUMMARY In an observer blind comparative study, 130 men with penile warts were randomly allocated to treatment with either cryotherapy or trichloroacetic acid (TCAA). There was no significant difference in response to treatment, side effects, or recurrence rates between the two treatments. Warts resolved in $81 \%$ of patients treated with TCAA compared with $88 \%$ of those treated with cryotherapy. Early recurrence occurred in $36 \%$ of patients treated with TCAA and in $39 \%$ of those treated with cryotherapy.

Genital warts are a common sexually transmitted disease and appear to be increasing in incidence. ${ }^{1}$ The mainstay of treatment is by local application of destructive or cytotoxic agents. Cryotherapy has been shown to be a useful treatment for genital warts. ${ }^{2-4}$ We have compared it with the local application of trichloroacetic acid (TCAA), another commonly used local destructive treatment.

\section{Patients and methods}

Heterosexual men with penile warts attending the department of genitourinary medicine at St Thomas' Hospital from May 1983 to July 1985 were invited to join the study. They were excluded if they had been treated for warts in the previous eight weeks, if they had warts at sites other than the penile shaft, prepuce, or glans, or if intrameatal warts were present.

At the first visit all patients were screened for other sexually transmitted disease (STD), as described elsewhere. ${ }^{5}$ Sexual partners were seen and examined for genital warts and other sexually transmitted disease, and treated as necessary. Patients were advised to use condoms during the period of treatment and follow up.

Patients were randomly allocated to treatment by local application of TCAA or cryotherapy. TCAA was applied to the wart with an orange stick to avoid the surrounding skin. Starch talc was then applied to prevent contamination of adjacent skin. Cryotherapy consisted of liquid nitrogen applied to the wart using

Address for reprints: Dr M J Godley, Department of Genitourinary Medicine, Royal Berkshire Hospital, London Road, Reading, Berkshire RGI 5AN.

Accepted for publication 14 March 1987 a fine nozzle spray gun (Cryak Unit, Alcon Laboratories, UK). Each wart was frozen for 15 seconds, allowed to thaw out, and refrozen for 15 seconds if this was tolerated. No local anaesthetic or lubricant was used.

The patients were reviewed at weekly intervals by an independent observer who had no knowledge of the treatment given. Treatment was repeated each week until the warts had completely disappeared. If they had not disappeared after 10 treatments, treatment failure was recorded and the alternative treatment was offered.

All patients who had been successfully treated were recalled two months after the end of treatment and examined for the presence of warts.

\section{STATISTICAL METHODS}

The time for complete regression of each patient's warts was compared between the two treatment groups. As warts were still present at the end of the treatment period in some patients, the comparison was made using a life table approach. The significance of differences was calculated using a log rank test. ${ }^{6}$ As some patients attended irregularly for treatment, the analysis was repeated using the number of treatments instead of duration.

\section{Results}

Of 130 men who entered the study, 23 failed to attend regularly and were withdrawn. One patient treated with cryotherapy was withdrawn because of severe side effects. Of 69 patients treated with TCAA, 57 $(85 \%)$ completed the study compared with 49 of 61 $(80 \%)$ treated with cryotherapy. The characteristics of patients in each treatment group who completed 
Table 1 Characteristics of 106 men with genital warts (61 of whom were experiencing their first episode) treated with trichloroacetic acid (TCAA) or cryotherapy

\begin{tabular}{|c|c|c|c|c|}
\hline \multirow[b]{2}{*}{ Characteristics } & \multicolumn{2}{|l|}{ All } & \multicolumn{2}{|l|}{ Ist episode } \\
\hline & $\operatorname{TCAA}(n=57)$ & Cryotherapy $(n=49)$ & $T C A A(n=34)$ & Cryotherapy $(n=27)$ \\
\hline $\begin{array}{l}\text { Median (range): } \\
\text { Age (years) } \\
\text { Duration of warts (weeks) } \\
\text { No of warts }\end{array}$ & $\begin{array}{c}24(18-64) \\
6(1-300) \\
6(1-32)\end{array}$ & $\begin{array}{c}24(19-44) \\
5(1-125) \\
6(1-60)\end{array}$ & $\begin{array}{c}24(18-64) \\
6(1-170) \\
9(1-32)\end{array}$ & $\begin{array}{c}23(19-30) \\
6(1-104) \\
6(1-60)\end{array}$ \\
\hline $\begin{array}{l}\text { Ethnic group: } \\
\text { White } \\
\text { Black } \\
\text { Asian }\end{array}$ & $\begin{array}{r}51 \\
5 \\
1\end{array}$ & $\begin{array}{r}40 \\
8 \\
1\end{array}$ & $\begin{array}{r}31 \\
3 \\
0\end{array}$ & $\begin{array}{r}23 \\
4 \\
0\end{array}$ \\
\hline $\begin{array}{l}\text { Associated STD: } \\
\text { Nil } \\
\text { Non-gonococcal urethritis } \\
\text { Gonococcal urethritis } \\
\text { Genital herpes } \\
\text { Candidal balanitis }\end{array}$ & $\begin{array}{r}35 \\
18 \\
1 \\
2 \\
1\end{array}$ & $\begin{array}{r}33 \\
14 \\
1 \\
0 \\
1\end{array}$ & $\begin{array}{r}20 \\
11 \\
1 \\
1 \\
1\end{array}$ & $\begin{array}{r}16 \\
10 \\
0 \\
0 \\
1\end{array}$ \\
\hline $\begin{array}{l}\text { Site of warts: } \\
\text { Prepuce } \\
\text { Glans } \\
\text { Shaft } \\
\text { Prepuce and glans } \\
\text { Prepuce and shaft } \\
\text { Shaft and glans }\end{array}$ & $\begin{array}{r}35 \\
1 \\
14 \\
3 \\
4 \\
0\end{array}$ & $\begin{array}{r}26 \\
0 \\
9 \\
10 \\
3 \\
1\end{array}$ & $\begin{array}{r}21 \\
1 \\
7 \\
3 \\
2 \\
0\end{array}$ & $\begin{array}{r}14 \\
0 \\
3 \\
9 \\
0 \\
1\end{array}$ \\
\hline
\end{tabular}

the study are compared in table 1 . The proportion of patients in each group with a history of genital warts was similar. There was no significant difference between the two treatment groups in patient or lesion characteristics. Patients with first episodes of genital warts were analysed separately.

The outcome of treatment is shown in table 2 . .There was complete resolution of warts within the treatment period in $46(81 \%)$ of those treated with TCAA and $43(88 \%)$ of those treated with cryotherapy. The mean number of visits required to clear all warts was four in the TCAA group compared with three in the cryotherapy group. Comparison of the two treatments by duration of treatment or by num- ber of treatments showed that patients treated with cryotherapy were 1.4 times more likely to respond to treatment within any given period, but the difference was not significant.

Of the patients who had been successfully treated within the treatment period, $85 \%(39 / 46)$ of those treated with TCAA and $88 \%(38 / 43)$ of those treated with cryotherapy attended for follow up. Recurrence occurred within two months of treatment in $36 \%$ (14/39) of the TCAA group compared with $40 \%$ $(15 / 38)$ of those treated with cryotherapy.

Side effects (local discomfort, ulceration, and scab formation) were more common with TCAA, but the difference was not significant. The one patient with-

Table 2 Outcome of treatment with trichloroacetic acid (TCAA) or cryotherapy of 106 men with genital warts (61 of whom were experiencing their first episode)

\begin{tabular}{|c|c|c|c|c|}
\hline \multirow[b]{2}{*}{ Outcome of treatment } & \multicolumn{2}{|l|}{ All } & \multicolumn{2}{|l|}{ Ist episode } \\
\hline & $T C A A(n=57)$ & Cryotherapy $(n=49)$ & $\operatorname{TCAA}(n=34)$ & Cryotherapy $(n=27)$ \\
\hline $\begin{array}{l}\text { No }(\%) \text { with complete resolution of warts } \\
\text { within treatment period } \\
\text { Mean No (1SD) treatments to complete }\end{array}$ & $46(81)$ & $43(88)$ & $27(79)$ & $22(82)$ \\
\hline resolution of warts & $4 \cdot 0(2 \cdot 3)$ & $3 \cdot 0(2 \cdot 2)$ & $4 \cdot 3(2 \cdot 2)$ & $3 \cdot 8(2 \cdot 7)$ \\
\hline $\begin{array}{l}\text { Follow up: } \\
\text { Information on } \\
\text { No }(\%) \text { with recurrence }\end{array}$ & $\begin{array}{l}39 \\
14(36)\end{array}$ & $\begin{array}{l}38 \\
15(40)\end{array}$ & $\begin{array}{l}23 \\
10(44)\end{array}$ & $\begin{array}{l}17 \\
10(59)\end{array}$ \\
\hline $\begin{array}{l}\text { Side effects: } \\
\text { Mild (discomfort only) } \\
\text { Moderate (ulceration/scabbing) } \\
\text { Severe (withdrawn from trial) }\end{array}$ & $\begin{array}{r}3 \\
26 \\
0\end{array}$ & $\begin{array}{r}9 \\
10 \\
1\end{array}$ & $\begin{array}{r}2 \\
16 \\
0\end{array}$ & $\begin{array}{l}7 \\
6 \\
1\end{array}$ \\
\hline
\end{tabular}


drawn from the study because of severe local discomfort with swelling, blistering, and ulceration had been treated with cryotherapy.

\section{Discussion}

These findings indicate that cryotherapy offers little benefit over TCAA in the treatment of genital warts. Response to treatment was faster with cryotherapy than with TCAA and side effects were less common, but the differences were not significant. Recurrence rates were high with both treatments.

The multiplicity of methods that have been used for the treatment of genital warts ${ }^{7}$ suggests that none is particularly effective. Treatment is often prolonged and time consuming, and recurrence is common. Patient compliance may be difficult to maintain, and treatment failure or relapse may be difficult to distinguish from reinfection. The end point of treatment may be difficult to define as resolving or early warts, scar tissue, and physiological skin blemishes may be indistinguishable from each other. For all these reasons few comparative trials have been reported, and comparisons between different studies are difficult as recommended regimens vary in frequency, amount, and duration of treatment.

Effective treatment is essential for the increasing numbers of patients with genital warts, especially in view of the malignant potential of certain types of the causative human papilloma virus (HPV). ${ }^{8}$ There seems to be no prospect of an antiviral agent or vaccine against HPV in the near future, so it is important that, despite the difficulties, the currently available methods are evaluated by further studies.

We thank Alcon Laboratories for lending the Cryak Unit, and Richard Morris of the Department of Community Medicine, United Medical and Dental School, St Thomas's Hospital, for help with the statistical analysis.

\section{References}

1 Communicable Disease Surveillance Centre. Sexually transmitted disease surveillance in Britain-1984. $\mathrm{Br}$ Med $J$ 1986;293:942-3.

2 Ghosh AK. Cryosurgery of genital warts in cases in which podophyllin treatment failed or was contraindicated. British Journal of Venereal Diseases 1977;53:49-53.

3 Balsdon MJ. Cryosurgery of genital warts. British Journal of Venereal Diseases 1978;54:352-3.

4 Simmons PD, Langlet F, Thin RNT. Cryotherapy versus electrocautery in the treatment of genital warts. British Journal of Venereal Diseases 1981:57:273-4.

5 Bradbeer CS, Thin RN. Comparison of econazole and isoconazole as single dose treatment for vaginal candidosis. Genitourin Med 1985;61:396-8.

6 Peto R, Pike MC, Armitage P, et al. Design and analysis of randomised controlled trials requiring prolonged observation of each patient. II. Analysis and examples. Br J Cancer 1977;35:1-39.

7 Kinghorn GR. Genital papillomavirus infection: treatment. In: Oriel JD, Harris JRW, eds. Recent advances in sexually transmitted diseases. No 3. Edinburgh: Churchill Livingstone, 1986:147-56.

8 McCance DJ. Genital papillomavirus infections: virology. In: Oriel JD, Harris JRW, eds. Recent advances in sexually transmitted diseases. No 3. Edinburgh: Churchill Livingstone, 1986:109-26. 